\title{
Tendências contemporâneas do teatro brasileiro
}

\author{
SÁBATO MAGALDI
}

S E A MODERNIDADE do teatro brasileiro pode ser datada de 1943 com a estréia de Vestido de noiva, talvez o marco da contemporaneidade caiba ser definido como o ano de 1978 pelo lançamento de Macunaima e pelo fim do Ato Institucional $\mathrm{n}^{\circ} 5$, de 13 de dezembro de 1968. Início da fase do domínio dos encenadores-criadores, a partir da montagem de Antunes Filho para a adaptação cênica da Rapsódia de Mario de Andrade, e abrandamento da censura, que levou à mudança da linha da dramaturgia desde o Golpe Militar de 1964.

Costumo afirmar que, didaticamente, certas hegemonias são reconhecíveis no palco brasileiro. Enquanto se realizava, em São Paulo, a Semana de Arte Moderna de 22, o atraso teatral ainda determinou, na década de 20 prolongando-se até a de 30, a hegemonia do ator. O fenômeno Vestido de noiva, que renovou a dramaturgia, com o texto de Nelson Rodrigues, a encenação, com o trabalho de Ziembinski, e a cenografia, com a arquitetura cênica de Santa Rosa, só produziu frutos imediatos e mais visíveis no campo das montagens. Prolongando e consolidando as criações do grupo carioca amador de Os comediantes, o Teatro Brasileiro de Comédia (TBC), criado em São Paulo em 1948, estabeleceu a hegemonia do encenador com o concurso dos diretores europeus, sobretudo italianos, que também na década de 50 assumiram as rédeas de conjuntos como o Teatro Popular de Arte (Companhia Maria Della Costa-Sandro Polloni), a Companhia Tônia-Celi-Autran, o Teatro Cacilda Becker e o Teatro dos Sete.

A hegemonia do autor brasileiro só veio a se dar em 1958 quando o Teatro de Arena de São Paulo lançou Eles não usam black-tie, de Gianfrancesco Guarnieri, abrindo caminho para um grupo de jovens talentos. A política de prestígio ao dramaturgo nacional deixou de ser privilégio do elenco paulista para dominar até os redutos que lhe eram mais adversos.

O florescimento da literatura dramática brasileira tornou-se signo da nossa maturidade artística e eis que o Golpe Militar de 1964 - desastroso em todos os sentidos - trouxe para o palco a hegemonia da censura. Ela não veio de repente, como se houvesse outras prioridades a cumprir. A sobrevivência do teatro tornou-se difić́lima com a edição do Ato Institucional n ${ }^{\circ} 5$ e o advento do governo Medici, que sufocou o que ainda restava de liberdade. No palco só se passou a respirar de novo com a abertura política iniciada no governo Geisel e prosseguida no governo Figueiredo.

A linguagem corrente foi a da metáfora ou, como disse Guarnieri para 
definir sua produção na década de 70, era possível apenas fazer um "teatro de ocasião". O anseio anônimo de liberdade estimulou os autores a concentrarem-se numa dramaturgia social e política, inimiga das injustiças que advogava a igualdade entre os brasileiros.

O fim da ditadura criou, sob o prisma autoral, inevitável vazio, já que não mais se justificava a mobilização dos autores no combate ao arbítrio. Não que ele deixasse de assumir novas formas, sempre condenáveis. O recurso à metáfora é que já não correspondia às necessidades do momento. Tanto que não funcionou para o público a peça Patética, na qual João Ribeiro Chaves Netto transpôs para o palco, em 1980, a biografia romanceada de seu cunhado - o jornalista Wladimir Herzog - assassinado pelos órgãos repressores. Já Campeões do mundo, de Dias Gomes, fez em 1979 o balanço do que ocorreu desde o Golpe de 64, sem qualquer artifício exigido pela censura, inaugurando assim nova fase do discurso direto.

Explicação verossímil para um certo declínio da dramaturgia na década de 80 é que, desmobilizados os autores na sua faina política, se requeria um tempo razoável para se reabastecerem com novos materiais do interesse do público. A maturação, sob o estímulo da realidade, demanda uma experiência que não se improvisa. Era natural que o palco cedesse espaço para outras preocupações.

Tais preocupações, por sua vez, não eram gratuitas. No passado, Sófocles, Shakespeare e Molière dirigiram as próprias peças. Mesmo os encenadores modernos, que desde a segunda metade do século XIX renovaram o espetáculo teatral colocando sob a sua batuta o conjunto da montagem, na maioria dos casos diziam estar a serviço do dramaturgo. Chegou-se a proclamar que a melhor encenação se qualificava como aquela que não aparecia. Não obstante algumas liberdades tomadas pelos encenadores que tiveram a sua hegemonia no Brasil nas décadas de 40 e 50, esse era, em síntese, seu ideário estético.

Uma forte tendência do teatro contemporâneo em todo o mundo, com repercussão entre nós, alterou essas premissas em virtude de novos pressupostos teóricos. O reconhecimento do teatro como arte autônoma, embora devedora de várias formas artísticas, e não mera ilustração da literatura, provocou importantes mudanças práticas. Admite-se hoje que, se o dramaturgo é o autor do texto, o encenador é o autor do espetáculo. E, pela autoria, compete-lhe assumir uma criação. Criação sui generis, já que fundada em outras, mas que tem o direito de aspirar à plenitude.

Essa criação ora configura-se com maior modéstia, quando o encenador preserva o texto integral e apenas troca as vestimentas antigas pelas atuais; ora intervém na peça, reduzindo os diálogos ou juntando outras obras do autor no mesmo espetáculo; ora adaptando, com ou sem auxílio de outrem, literatura de gênero diverso para o palco; ora, enfim, assumindo a inteira responsabilidade por texto e espetáculo. Se o encenador não encontra, em determinado instante, peça pronta que exprima as preocupações do seu universo, é absolutamente legítimo que procure a criação integral. 
As referências internacionais mais próximas para o nosso público ou para os nossos artistas têm sido, no teatro, Victor Garcia, Robert Wilson, Peter Brook e Tadeusz Kantor; na dança, Kazuo Ohno e Pina Baush. Victor Garcia encenou em São Paulo, em 1968, Cemitério de automópeis, que não se limitava ao texto de Arrabal com aquele título, mas agregava a ele três outras obras do autor: Primeira comunhão, A oração e Os dois carrascos. Antunes Filho, ao realizar, em 1981, Nelson Rodrigues o eterno retorno, sintetizou a sua visão do universo do dramaturgo também em quatro textos: Álbum de familia, Os sete gatinhos, Beijo no asfalto e Toda nudez será castigada, reduzindo-o, depois, em Nelson 2 Rodrigues, a Álbum de família e Toda nudez será castigada.

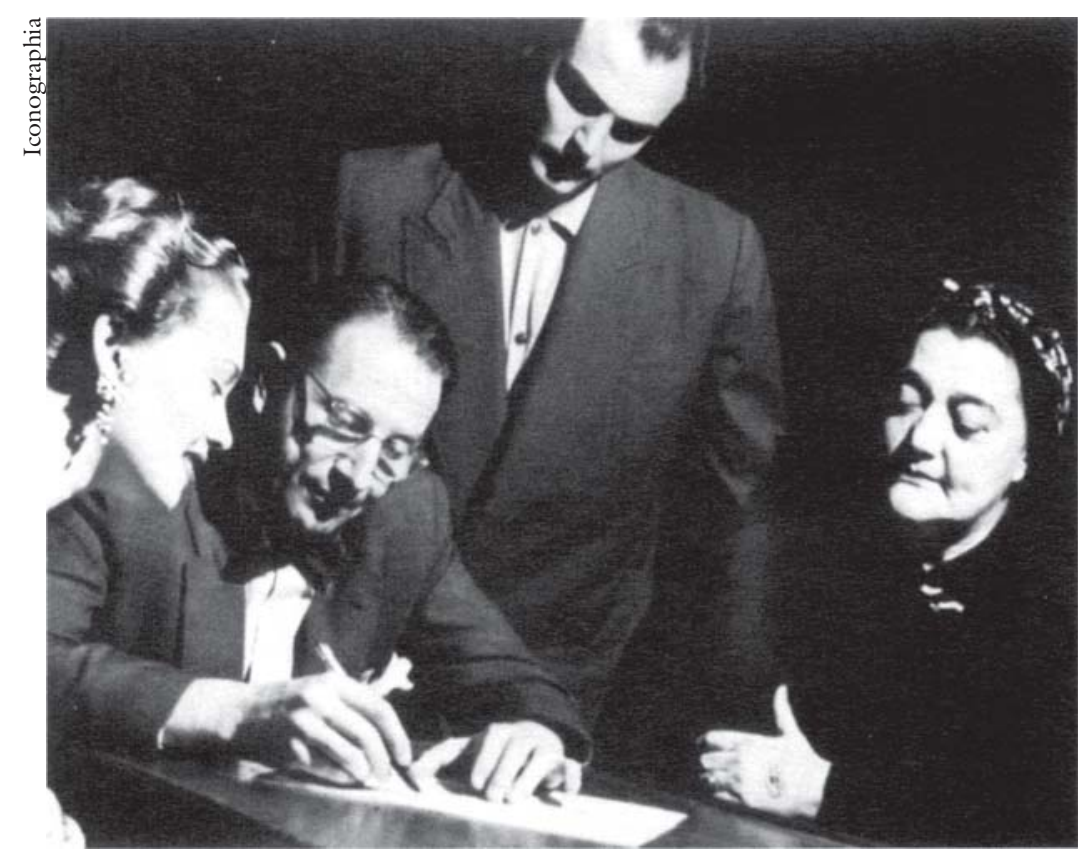

Em pé, Sandro Polonio (produtor); da esq. para dir., Maria Della Costa, Ziembinsky e Itália Fausta, 1948.

Cena de Vestido de noiva, de Nelson Rodrigues, 1943.

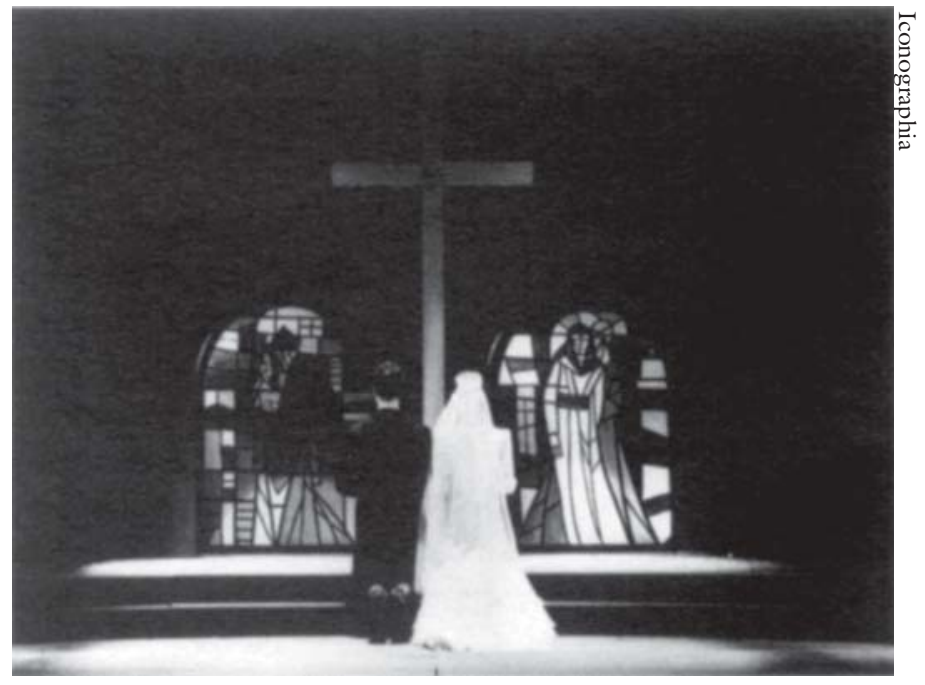


Em sua pioneira trajetória artística, Antunes Filho tem utilizado, segundo as conveniências de cada criação, um dos modelos de intervenção acima resumidos: em Macunaina, a adaptação do romance de Mário de Andrade realizada por Jacques Thériot e pelo Grupo Pau Brasil, de acordo com as necessidades do espetáculo que concebeu; em Romen e Julieta, a música dos Beatles em lugar das composições da época; em Xica da Silva, peça de Luiz Alberto de Abreu de cujas diretrizes divergiu, conservando o nome do autor mas tomando liberdades com o texto; em Vereda da salvação, enxugando o diálogo de Jorge Andrade; em Paraiso Zona Norte, igualmente enxugando A falecida e Os sete gatinhos de Nelson Rodrigues, emprestando-lhes nova ambientação e novas vestimentas; em A hora e vez de Augusto Matagra, dramatizando a narrativa de Guimarães Rosa; em Nova velha história, adaptando sem palavras o conto Chapeuzinho vermelho; e, em Gilgamesh, transpondo para o palco a epopéia do herói do mesmo nome, rei de Uruk, na Mesopotâmia, que precedeu ao menos de um milênio e meio a saga homérica. Cauteloso, Antunes Filho preferiu sempre apoiar-se em obras literárias alheias que permitem maior segurança ao seu vôo criador.

Gerald Thomas, outro encenador de talento, soube privilegiar sempre o aspecto visual, a princípio na sua produtiva parceria com a cenógrafa Daniela Thomas. Sem sucumbir ao formalismo vazio, o impacto inicial vinha de poderosas imagens articuladas no todo da montagem. Meu primeiro contato com o seu trabalho deu-se no Rio de Janeiro, onde se lançaram Quatro vezes Beckett e um texto de Heiner Müller, Quartett. A força da dramaturgia conjugava-se perfeitamente com a originalidade e a precisão dos recursos cênicos empregados. Não tive a oportunidade de assistir a algumas de suas criações, o que me impede de tentar um juízo generalizador. Do que vi, creio que ao utilizar uma dramaturgia sólida sentiu-se mais à vontade para chegar a um resultado artístico pleno. Até na triologia Kafka, O processo, cuja adaptação transpunha a dramaticidade contida no romance original, o rendimento era superior; A metamorfose padecia da pouca teatralidade do tema; e Praga não alcançou um universo ficcional definido. Também Flash and crash day não atinge o estatuto de completa obra artística, perdendo-se na brincadeira de que logo se esquece. Está claro que, pela inteligência e pelo mérito de que já deu mostra, Geraldo Thomas a qualquer momento pode superar suas imperfeições literárias e produzir uma obra-prima de sua inteira autoria.

Num instante mais radical de iconoclastia antiacadêmica, Ulisses Cruz aderiu a um teatro de imagens que parecia julgar a palavra um apêndice incômodo do fenômeno teatral. Por isso consumiram-se no vazio produções como Cândida Erêndira, inspirada em Garcia Marquez. Talvez a fase do exagero prejudicial fosse necessária, para o encenador, não abdicando da própria concepção do espetáculo, retornar a um equilíbrio fecundo. Ele começou a despontar em Desejo, de O'Neill, embora comprometido por desavenças com o elenco. Anjo negro, difícil tragédia de Nelson Rodrigues, mereceu de Ulisses uma leitura de absoluta fidelidade e compreensão. E Péricles rejuvenesceu, no mágico espaço cênico de Hélio Eichbauer, a trama fantástica da tragédia shakesperiana. 


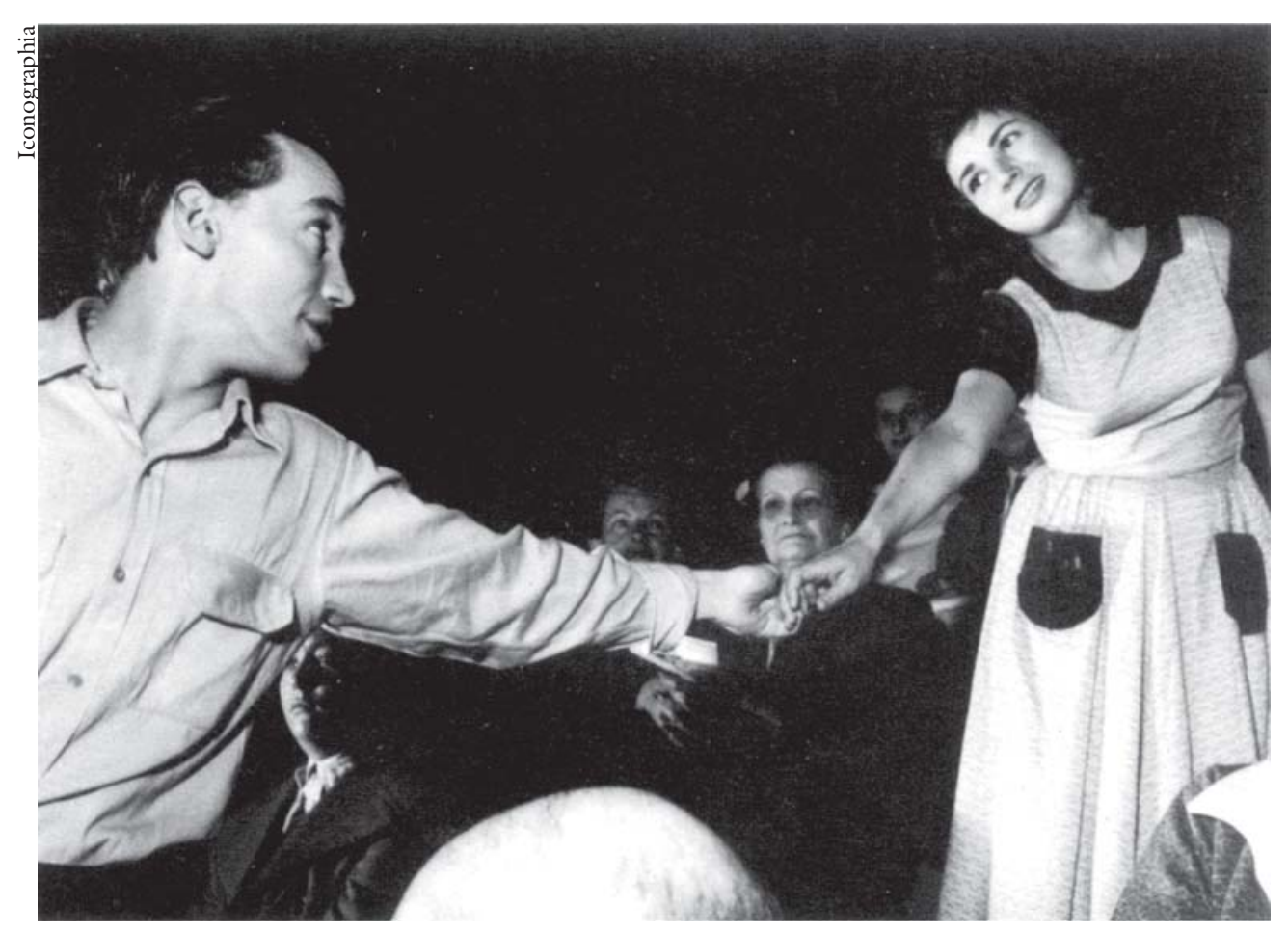

Eles não usam black-tie: • Gianfrancesco Guarnieri contracenando com Miriam Meheler, 1958.

Neste ponto, reúno alguns dos nomes saídos do atual Departamento de Artes Cênicas da Escola de Comunicações e Artes da Universidade de São Paulo. Em comum, eles têm apenas a circunstância de poderem figurar no grupo dos encenadores-criadores, já que seus caminhos individuais não se confundem. Acredito que os cursos freqüentados lhes deram base para depois, por conta própria, se entregarem à aventura pessoal.

Cronologicamente, o primeiro encenador a obter êxito amplo foi José Possi Neto em 1984, com a montagem da peça De braços abertos, de Maria Adelaide Amaral. Ele soube inocular no palco uma atmosfera mágica, em que a luz dirigia a flexibilidade dos movimentos, evitando os prosaicos pormenores realistas, para instaurar a fluência do sonho.

Pena que a morte prematura tenha roubado do teatro Luiz Roberto Galizia - autor do belo ensaio Os processos criativos de Robert Wilson -, que trouxe para as suas experiências a vitalidade do desempenho. Francisco Medeiros, responsável, a meu ver, pela mais convincente materialização cênica das teorias de Antonin Artaud, não tem trabalhado com a continuidade que seria de desejar. Igual observação se aplicaria a William Pereira que, depois de um criativo Leonce e Lena e de êxitos como Uma relação tão delicada e Senhorita Júlia, se especializou no campo da ópera.

Cacá Rosset, diretor do Ornitorrinco, um dos poucos grupos a ostentar um perfil identificável, vem conseguindo desempoeirar os clássicos, tratados por 
ele como contemporâneos. De Brecht a Shakespeare a agora de novo ao Jarry, de $U b u$ - texto que há um século indicava os procedimentos da vanguarda -, ele evitou os riscos museológicos da submissão passiva e escolheu a irreverência que se encontrava no cerne de suas obras, obtendo a cumplicidade franca da platéia.

Diferentemente de Flávio Império, que foi buscar no Teatro de Palladio em Vicenza, na Itália, o modelo para vestir o palco nu recomendado por Nelson Rodrigues em $A$ falecida, Gabriel Villela extraiu do texto os signos de seu inventivo cenário. No fundo, tacos de sinuca, dispostos à maneira de velas num altar. No chão, a própria mesa de jogo, e o pano verde, no final, sugerindo o campo de futebol, última jornada do protagonista em desespero. Em síntese admirável, todos os ambientes da tragédia carioca estão contidos no espaço da cena. Em outras montagens, Gabriel Villela incorporou ao palco reminiscências barrocas de sua Minas natal, fundindo-as na mesma atmosfera mítica. O mambembe, apesar de seus aspectos positivos, entre os quais a mala a simbolizar o título, diluiu a bela construção dramática de Artur de Azevedo, que perdeu a sua organicidade, sem que entrasse no lugar outro valor palpável.

Antonio Araújo, afinado com uma das vertentes da estética atual, procura fugir dos teatros convencionais e localiza $O$ paraíso perdido - adaptado do poema de Milton - dentro de uma igreja, e o bíblico O livro de Jó - que Luiz Alberto de Abreu transformou em peça - nos múltiplos recintos de um hospital. As possibilidades de exploração do espaço enriquecem sobremaneira o rigor criativo de Antonio Araújo.

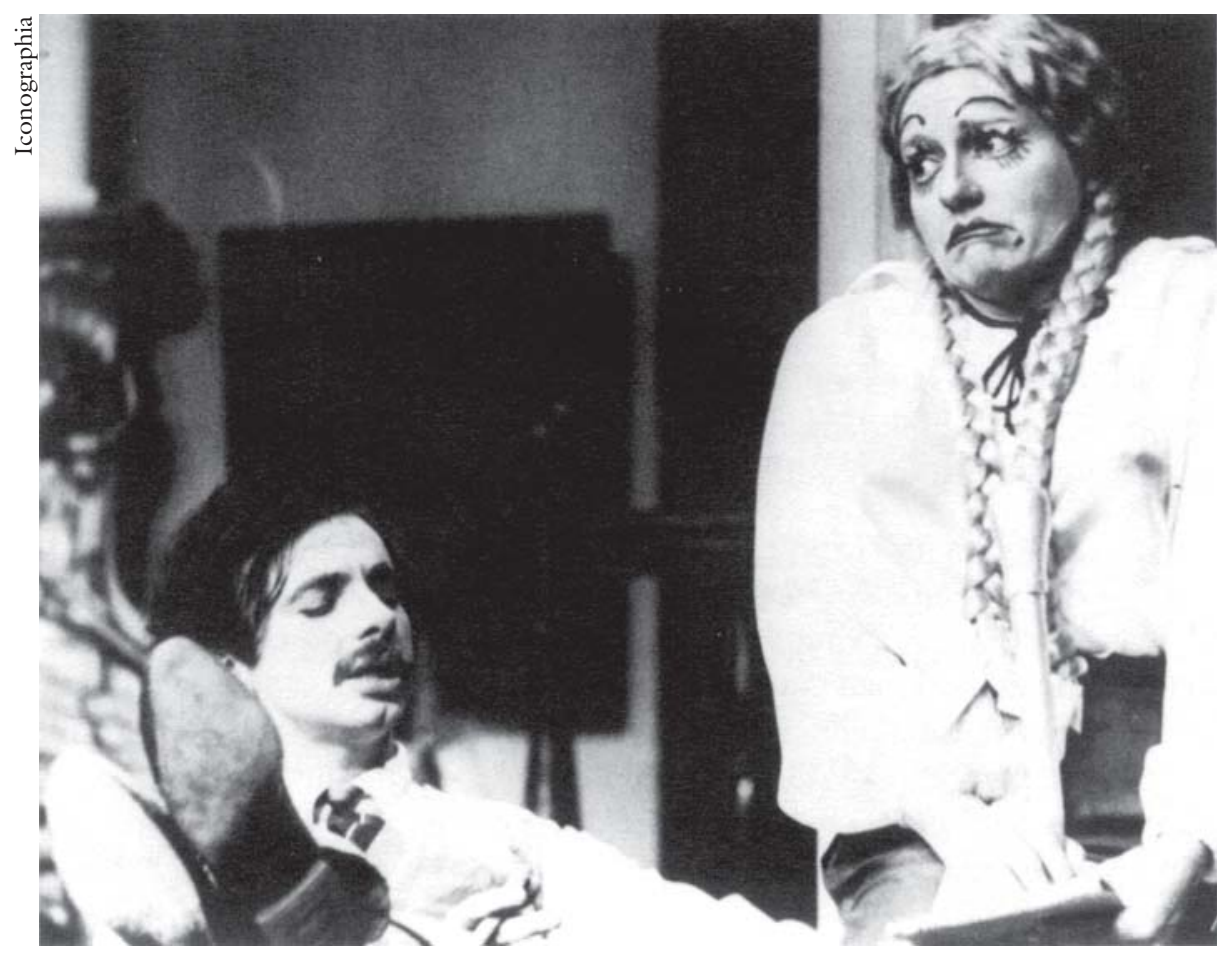

Cena de O rei da vela: Renato Borghi contracenando com Liana Duval, 1967. 
Eduardo Tolentino de Araújo, que havia feito em Viúva porém honesta uma das leituras mais originais de Nelson Rodrigues, conduz com mão firme o Grupo Tapa originado no Rio de Janeiro há mais de uma década, e recebe o reconhecimento da crítica ao realizar expressivo panorama do teatro brasileiro. Um juízo superficial o consideraria menos audacioso que outros encenadorescriadores. Basta ver os espetáculos Vestido de noiva e Rasto atrás para concluir que, sob a aparência nada bombástica das duas montagens, surge uma imagem profunda dos textos. Pela primeira vez a obra de Nelson Rodrigues conseguiu desligar-se, de forma convincente, do fantasma da encenação histórica de Ziembinski. O aproveitamento plástico dos espelhos sugeriu, com extrema mobilidade, $\mathrm{o}$ intercâmbio permanente entre os planos da realidade, da memória e da alucinação. E o exigente texto de Jorge Andrade, que recorre ao protagonista em várias idades e, em certas cenas as coloca todas no palco em diálogo simultâneos, não perde em momento algum a clareza. Tolentino teve a coragem de enfrentar verdadeiros tabus da dramaturgia brasileira e imprimir-lhes um tratamento contemporâneo.

Vários outros encenadores, que vêm de fases de diferente inspiração, não perderam a atualidade e continuam forças vivas do nosso palco. Mencionam-se, entre eles, José Celso Martinez Corrêa, Antonio Abujamra, Celso Nunes, Fauzi Arap e Marcio Aurélio. E deixei de lado encenadores mais conhecidos do público no Rio, entre os quais Aderbal Freire-Filho, Moacyr Góes, Bia Lessa e Marcio Vianna, há pouco falecido, que vimos em São Paulo na esplêndida montagem de O futuro dura muito tempo, sobre a tragédia de Louis Althusser.

A par da necessidade de procurar novas fontes, depois da abertura política, há de se entender que a passagem dos encenadores-criadores ao primeiro plano, iniciada com Macunaína, intimidou um pouco os dramaturgos. Em grande parte, sentiram-se desestimulados a cumprir a própria trajetória, que não se ajustava à tendência todo-poderosa dos diretores. Veja-se o caso de Maria Adelaide Amaral. Era natural que depois do imenso êxito da peça De braços abertos, em 1984, todos os seus textos fossem imediatamente apresentados. No entanto, ela precisou esperar várias temporadas para que subissem à cena Querida mamãe e Intensa magia, que obtiveram também grande sucesso. A falta de resposta imediata à legítima aspiração de ser encenado obriga o autor a tentar outros veículos, dos quais o mais pródigo é a televisão.

Exceção, nesse quadro, chama-se Nelson Rodrigues. Desde a estréia de $O$ eterno retorno, em 1981, logo após a sua morte, passou a ser mitificado. Descobriu-se que era um clássico, e os clássicos se prestam às mais controvertidas exegeses, pela riqueza inesgotável de sua obra. Cada encenador pretendeu mostrar a sua leitura de Nelson, a ponto de dizerem que os herdeiros deveriam retirálo do mercado de espetáculos, sob pena de o público sofrer uma indigestão. Esse temor felizmente não se confirmou, porque a temporada de 1994 foi das mais felizes no sentido de oferecer uma reavalização positiva do dramaturgo, em virtude das montagens de A falecida, por Gabriel Villela; Anjo negro, por Ulisses Cruz; Senhora dos afogados, por Aderbal Freire-Filho; e Vestido de noiva, por 
Eduardo Tolentino de Araújo. À semelhança do que sucede a Shakespeare, cada peça de Nelson deveria ser periodicamente remontada.

Antunes Filho iniciou o processo de relançamento de Jorge Andrade com Vereda da salvação, e Eduardo Tolentino secundou-o com Rasto atrás, texto que de forma absurda se encontrava até recentemente inédito em São Paulo, estado natal do dramaturgo. Passado o purgatório a que é condenada a maioria dos autores após a morte, terá chegado o momento de sua ascensão ao paraíso? Oduvaldo Vianna Filho, após o êxito extraordinário de Rasga coração e Papa Highirte, também somente lançadas depois do afrouxamento da censura, permaneceu em injusto ostracismo até a recente remontagem de Corpo a corpo, feita por Eduardo Tolentino. Embora seu teatro empenhado não corresponda ao gosto do dia, os valores perenes que defende deveriam ser sempre ouvidos.

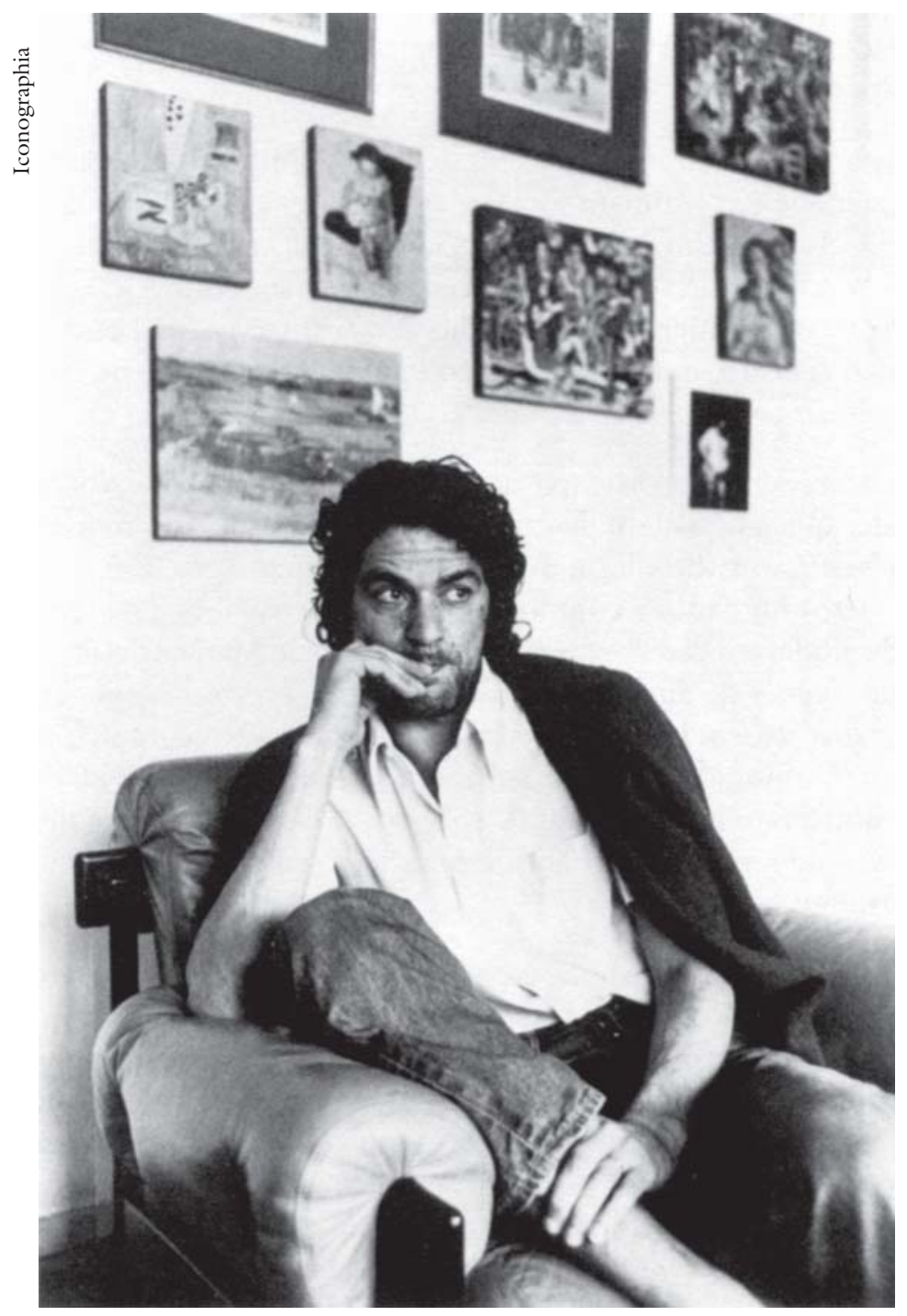

Oduvaldo Vianna Filho, o Vianinha. 


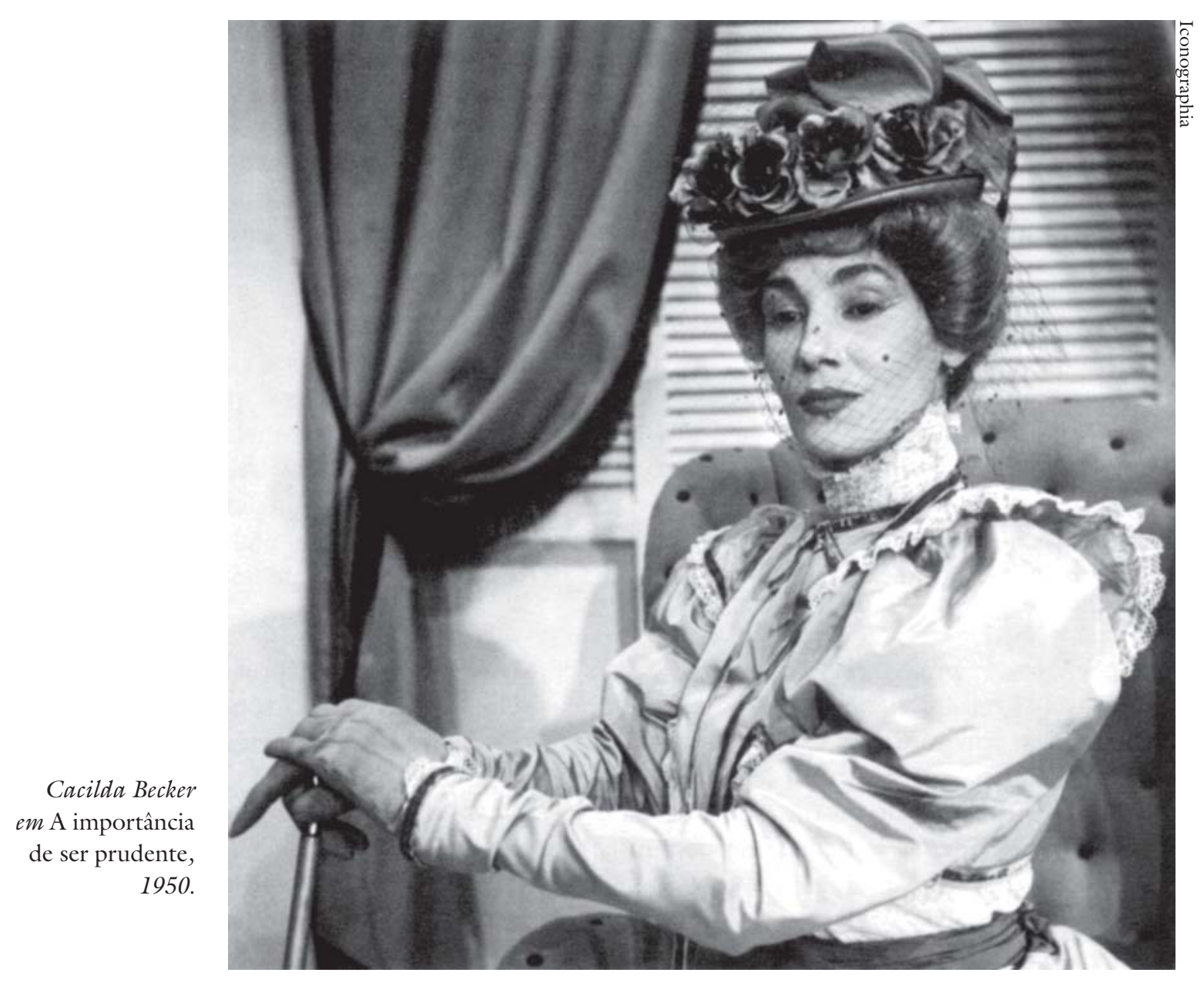

Outros dramaturgos, por motivos diversos perderam o interesse dominante pelo teatro. Ariano Suassuna desviou-se, ao menos temporariamente, do palco pela necessidade de exprimir-se no romance, em que se notabilizou com as criações do Romance d'a pedra do reino e o Príncipe do sangue do vai-e-polta e O rei degolado. Gianfrancesco Guarnieri não tem sido bem-sucedido nas últimas incursões autorais. Augusto Boal passou a concentrar-se na teoria e na prática do Teatro do Oprimido, a contribuição única de um brasileiro a obter acolhida internacional.

Dias Gomes, sempre escrevendo para o palco, ao lado da criação regular de telenovelas, sente-se pouco à vontade no atual sistema utilizado para produzir espetáculos, tema que examinarei adiante. Plínio Marcos prossegue na ordem do dia, ainda sem a veemência dos anos 60. Lauro Cezar Muniz e outros nomes têm se dedicado de preferência à televisão, veículo que, aliás, assegura a sobrevivência de muitos artistas impossibilitados de garanti-la somente no teatro.

Naum Alves de Souza, que nos anos 70 trouxe para a cena uma sensibilidade delicada, não está conseguindo consolidar a sua dramaturgia nos últimos anos. 
As dificuldades quase insuperáveis para uma produção séria, hoje em dia, têm silenciado numerosos nomes promissores.

O espaço aberto pela dramaturgia séria, que não conseguiu articular uma nova linguagem ao liberar-se da censura, passou a ser ocupado por um gênero diferente da comédia e da revista, e que no batismo recebeu o nome muito significativo de besteirol. Sobretudo a cena carioca, talvez mais afeita às manifestações ligeiras, depressa entronizou a fórmula fácil, que se espalhou um pouco por toda parte.

Acostumando-me, no decorrer dos anos, a aceitar minhas limitações, confesso que tenho pelo besteirol indisfarçável horror. Por mais que ensaístas respeitáveis lhe atribuam uma categoria artística, acho-o apenas o produto de melancólica alienação, cuja responsabilidade deve caber, em grande parte, aos tristes tempos da ditadura. Não há nele o saudável nonsense do absurdo nem outro ingrediente apreciável, mas apenas a algaravia que beira a debilidade mental. É preciso reconhecer que se está mostrando cada vez mais escassa a lamentável perda de tempo com o besteirol.

É com prazer que registro a recuperação de Mauro Rasi que, depois da promissora estréia de $A$ massagem, havia aderido ao gênero. Ele reencontrou-se ao dramatizar a memória na triologia formada por A estrela do lar, A cerimônia do adeus e Viagem a Forli. O mergulho autobiográfico deu consistência a essa educação sentimental do autor, a qual acaba de se acrescentar, formando uma tetralogia, a peça Pérola, deflagrada pela morte de sua mãe. Ainda um tanto perdido, talvez pela dispersão excessiva a que entrega, Miguel Falabella, principalmente no monólogo Loiro, alto, solteiro, procura..., em que se socorre também de seu real talento de intérprete, parece às vésperas de engrossar a cadeia da boa dramaturgia.

\section{Problemas e desafios}

Sob o prisma artístico, a conclusão é a de que os vários desajustes estão sendo superados. $\mathrm{O}$ encenador, passada a ressaca da bebedeira criativa, deseja o equilíbrio com os outros elementos do espetáculo. A harmonia de todas as funções é o ideal perseguido. Por isso os diretores mais conscientes estão preocupados em aprimorar métodos de interpretação, já que a última palavra no diálogo com o público é dada mesmo pelo ator. Os malabarismos da imaginação ficam mudos se não se corporificam num bom desempenho. O dramaturgo toma cada vez mais consciência de que precisa escrever para a cena, tendo como mediador aquele que sabe materializar o seu mundo e o outro que empresta voz à sua palavra.

Não estou desmobilizando qualquer tendência e creio que, vencidos os excessos, todos contribuirão da melhor maneira para concretizar o teatro dos nossos sonhos, afinal, uma arte coletiva. Os verdadeiros problemas do palco não se encontram nele, quando se equacionam e se resolvem as divergências estéti- 
cas. Talentos maiores e menores o Brasil produz, sem conta. Tivessem eles oportunidade de atingir o público, nossa realidade cênica seria muito mais rica, diversificada e ninguém endossaria a crença segundo a qual o brasileiro não gosta de teatro. É verdade que o saudoso Anatol Rosenfeld diagnosticou terem o cinema e a televisão dominado os nossos hábitos, antes que se consolidasse o prazer do palco, o que não ocorreu na Europa. Penso, entretanto, haver outros motivos que dificultam o entendimento perfeito entre palco e platéia.

$\mathrm{O}$ mais grave refere-se às dificuldades para a produção. Mesmo no tempo da ditadura, o Estado subsidiava o teatro. Não importa recorrer a raciocínio de ordem moral, havendo os que pensam existir, nas subvenções, tentativa de compra das consciências. Tenho para mim que essa era uma prática já consolidada, que ninguém pensava em alterar. Lembre-se que na França, na Alemanha, na Itália e na Inglaterra, entre outros países adiantados, nunca se pôs em dúvida o apoio maciço à cultura. Na Alemanha dividida, a parte ocidental reservava para a bilheteria a função de cobrir apenas $20 \%$ do orçamento dos teatros oficiais, responsabilizando-se o Estado pelos 80\% restantes. Os Estados Unidos, paradigma da livre iniciativa, compreenderam a necessidade de amparar a cultura: o National Endowment for the Arts e as fundações colocaram sob as suas asas as iniciativas sérias, excluindo somente as de caráter abertamente comercial.

O advento da abertura pôs em circulação no Brasil uma filosofia perversa, como se a proteção à cultura nascesse de um lobby corporativista. O protecionismo campeava nas atividades econômicas que poderiam dispensá-la, ao passo que o Ministério da Cultura ficou reduzido à ridícula verba de $0,04 \%$ do orçamento da União. Evidentemente, com numerário que mal dava para o seu próprio custeio, o Ministério teve de abdicar de uma política de cultura, no que foi acompanhado pelos governos estaduais.

Diante do impasse criou-se a panacéia do recurso às leis de incentivo fiscal, delegando à iniciativa privada o papel de estímulo à cultura, em troca de benefícios de natureza fiscal. Considero essas leis muito úteis como coadjuvante no processo de valorização artística, mas nada justifica, por causa delas, que o Estado se omita. A continuidade da vida teatral não pode se subordinar ao arbítrio dos dirigentes de empresas particulares, por mais esclarecidos que sejam.

Fernanda Montenegro, atriz que ocupa posição privilegiada em nossa cena, assim se manifestou sobre o assunto, em matéria publicada em 6 de janeiro, no jornal $O$ Estado de S. Paulo: "Não estou defendendo uma total participação estatal no setor cultural, mas é preciso que exista uma coalizão, porque a empresa privada está interessada em outros resultados. Quando se pede um patrocínio, a empresa quer um nome famoso e um texto sem compromisso. Dias felizes foge à regra, mas não é comum que uma empresa se interesse por Beckett”.

No mesmo jornal, em 20 de janeiro, Renato Borghi foi mais incisivo: “ $\mathrm{Na}$ época da ditadura, você se apresentava previamente para o Deops e agora tem de se apresentar para o Café Caboclo, para a Phytoervas. O produto tem de 
corresponder ao que muitos apoios esperam de você como retorno. Então, essa palavra retorno, que é quantitativa, passa a exercer um fascínio. Dizem: 'Te dou o vinho tal durante a temporada, mas tenho que assistir antes a tua peça'. Ou seja, estou sendo julgado por firmas de vinho, café, maquiagem etc. Jogar a cultura para o patrocínio privado e o Estado se isentar completamente é uma política equivocada e uma traição para com a sociedade, que paga tributos e quer ver atuantes as secretarias de cultura dos governos. A arte é essa coisa maluca, insubordinada. E, de repente, tem de ficar domada, relacionada a esse retorno quantitativo". Um possível patrocinador do atual espetáculo de Renato Borghi Édipo de Tabas - perguntou se o protagonista não poderia se eximir de furar os próprios olhos, anulando a beleza e o significado da lenda e da tragédia sofocleana.

Seria injusto omitir que a atual administração do Ministério da Cultura está ciente da insatisfação provocada pela ausência de uma política específica de artes cênicas e pretende em breve implementá-la. Tomara que ela atenda ao reclamos do pessoal de teatro. E que seu exemplo seja seguido pelos organismos congêneres dos estados e dos municípios.

Cumpre admitir que outra dificuldade para o desenvolvimento harmonioso do teatro vem de sua insatisfatória divulgação. Utilizarei minha longa experiência na imprensa como comprovante das alegações. A partir de 1950, no Diário Carioca, eu mantinha uma coluna diária, preenchida com críticas, noticiário, reportagens e entrevistas. No jornal $O$ Estado de $S$. Paulo, em que Décio de Almeida Prado se demorava na análise fundamentada dos espetáculos, criei, em 1954, uma coluna diária de informações teatrais, de cerca de 100 linhas, secundada por colunas sobre música erudita e artes plásticas. A partir de 1956 eu fazia semanalmente, no Suplemento Literário, um longo comentário alusivo a quaisquer temas de teatro. Os empresários obtiveram da direção do jornal um desconto substancioso no anúncio dos famosos tijolinhos, e a publicidade, assim, não pesava no orçamento das companhias. Naquele tempo, a televisão e a música popular, de qualquer gênero, não tinham a honra de figurar no noticiário.

Os custos da produção jornalística elevaram-se, o espaço passou a ser disputado por maior número de eventos e o teatro perdeu, no decorrer das últimas décadas, a condição de arte privilegiada. Durante algum tempo, por exemplo, o Jornal da Tarde publicava uma seção semanal de teatro, substituída nos outros dias por seções semelhantes das demais artes, e todas foram suprimidas, enquanto se divulga uma seção diária de gente de tevê. Por múltiplos caminhos, o teatro se elitiza, o que na prática redunda em redução de espectadores e desestímulo ao preparo de maior número de montagens.

A década de 50 conheceu verdadeira explosão imobiliária, que acarretou o aparecimento de numerosas casas de espetáculos. Outros bairros continuam a surgir, mas ao crescimento demográfico não corresponde à construção de novos teatros. Ao contrário, a inviabilização econômica tem determinado o fechamento de vários espaços. Não se trata de perseguição ao teatro: o trabalho está cada vez menos disponível, num país que decidiu adotar um modelo equivocado. 
Num sistema que privilegiaria a iniciativa privada, paradoxalmente os proprietários particulares são forçados a se desvencilhar de seus teatros. Os custos de manutenção inviabilizam a continuidade. Por sua vez, por falta de verbas orçamentárias, desviadas para outras supostas prioridades, o Estado deixa em abandono as salas que construiu ou resolveu arrendar. Em São Paulo, a maioria dos bons teatros pertence a entidades: Sesc, Sesi, Aliança Francesa, Círculo Italiano, Hebraica. Advirto que, a prevalecerem as restrições que se pretende impor a alguns desses serviços, as iniciativas louváveis que eles desenvolvem, como o Centro de Pesquisa Teatral e o Teatro Popular, passam a correr sérios riscos.

É forçoso lembrar, por último, o incalculável dispêndio de energia a que se submete o pretenso espectador, numa megalópole, para sair de casa. Não se chega aos lugares em tempo razoável, as vias de acesso estão freqüentemente bloqueadas e não se tem segurança no trânsito. Entende-se, nesse quadro, a preferência por ligar a televisão, que ademais é de graça. Tudo parece conspirar contra a sobrevivência do teatro.

Há de se convir que os problemas o transcendem e sua solução depende de estratégias que desafiam os governantes. Uma verdade parece insofismável: sejam quais forem as tendências contemporâneas do palco brasileiro, a perenidade do teatro está assegurada pelo insubstituível diálogo dentre o ator e o público.

Sábato Magaldié crítico, historiador e professor de teatro. Deu aulas na Sorbonne (Universidade de Paris III) e na Universidade de Aix-en-Provence. Em julho de 95, tomou posse na Academia Brasileira de Letras. É autor de vários livros, entre eles Panorama do teatro brasileiro, Iniciação ao teatro, Nelson Rodrigues: dramaturgia e encenação e $O$ texto no teatro.

Conferência do Mês do IEA-USP feita pelo autor em 9 de abril de 1996 no auditório da Escola de Arte Dramática da USP. 